\title{
Standardized Post-mortem Forensic Examination Form
}

\author{
Standardize Adli Ölü Muayene Formu
}

\author{
(1) Mustafa Önder Polat MD.1, @ ( Çağdaş Meriç MD.2, (1) Gürcan Altun Prof. MD.3 \\ ${ }^{1}$ Trakya University Faculty of Medicine, Department of Forensic Medicine, Edirne, Turkey \\ 2Sultan $1^{\text {st }}$ Murat State Hospital, Edirne, Turkey \\ ${ }^{3}$ Trakya University Faculty of Medicine, Department of Forensic Medicine, Edirne, Turkey
}

\section{ABSTRACT}

In deaths considered not to arise from natural causes, the physician participating in the forensic death examination is asked to determine the possible time of death by evaluating the injuries on the body and post-mortem findings that have emerged on the corpse, and to give an opinion about the most likely cause of death. These examinations, which should primarily be performed by a forensic medicine specialist, are also conducted by physicians working in primary health care. In this study, we have aimed to develop a standardized form that we think will be a guide to provide convenience to physicians participating in forensic death examination.

While creating the post-mortem forensic examination form presented in this study, the general forensic examination reporting form recommended to be used in today's daily medical practice was taken as the sample. The form consisted of sections related to "determinants of medical identity", "post-mortem findings", "injury-related lesions", "probable cause of death according to findings in the examination" and "decision made". Body diagrams were added to mark the locations of the lesions on the corpse.

Certain standardization is achieved in the reports issued by the physician in forensic cases with the preparation of general forensic examination reporting forms. However, there is no standardized form used for forensic post-mortem examination in our country. As the time between postmortem examination and forensic autopsy increases, post-mortem findings on the corpse may change. Therefore, the findings observed during forensic post-mortem examinations should be accurately defined and recorded. Lacks or mistakes made during this process may cause critical problems in the functioning of the justice system.

We anticipate that the deficiencies in the post-mortem forensic examination process can be reduced by using this form, which has been shaped into a conformation suitable for the needs of physicians participating in a post-mortem examination.

Keywords: Forensic post-mortem examination, post-mortem changes, death time

Address for Correspondence/Yazıșma Adresi: Mustafa Önder Polat MD., Trakya University Faculty of Medicine, Department of Forensic Medicine, Edirne, Turkey

E-mail: musderpol@hotmail.com

ORCID ID: orcid.org/0000-0002-1092-6320
Received/Geliș tarihi: 28.01.2020 Accepted/Kabul tarihi: 11.09.2020 


\section{öz}

Doğal nedenlerden kaynaklanmadığı düșünülen ölümlerde; adli ölü muayenesine katılan hekiminden ceset üzerindeki yaralanmaları ve ölüm sonrası ortaya çıkan bulguları değerlendirerek olası ölüm zamanı ve ölüm nedeni hakkında görüş belirtmesi istenmektedir. Öncelikle adli tıp uzmanları tarafından yapılması gereken bu muayenelerin birinci basamakta yer alan hekimler tarafından da yapıldığı bilinmektedir. Bu çalışmada, adli ölü muayenesine katılan hekimlere yol gösterici olacağını düşündügüumüz standardize bir form geliştirilmesi amaçlandı.

Adli ölü muayenesi formu oluşturulurken uygulamada kullanılması önerilen genel adli muayene rapor formu örnek alındı. Form; tıbbi kimliğin belirlenmesine yönelik özellikler, ölüm sonrası ortaya çıkan bulgular, yaralanmaya ilişkin lezyonlar, muayene bulgularına göre olası ölüm nedeni ve kararla ilgili bölümlerden olușturuldu. Lezyonların ișaretleneceği vücut diyagramları eklendi.

Genel adli muayene rapor formları ile adli olgulara düzenlenen raporlarda belirli bir standardizasyon sağlandığı bilinmektedir. Ülkemizde adli ölü muayenesi için kullanılan standart bir form bulunmamaktadır. Ölü muayenesi ile otopsi arasındaki süre uzadıkça, ölüm sonrası ortaya çıkan bulgular değişebilmektedir. Bu nedenle, ölü muayenesi sırasında saptanan bulguların eksiksiz ve doğru tanımlanarak kayıt altına alınması gereklidir. Bu süreçte oluşan eksiklik ya da yanlıșlıklar adaletin ișleyișinde ciddi sorunlara yol açabilmektedir.

Ölü muayenesine katılacak hekimlerin gereksinimlerine uygun bir biçime dönüştürülecek bu formun kullanılmasıyla uygulamadaki eksikliklerin azaltılabileceği ön görülmektedir.

Anahtar Kelimeler: Adli ölü muayenesi, ölüm sonrası değișiklikler, ölüm zamanı

\section{INTRODUCTION}

According to the Criminal Procedure Code (CPC Art.159) in our country, if there is a circumstance that would raise the suspicion that death has not occurred due to natural causes or the identity of the deceased cannot be determined, law enforcement officers, village headmen or persons in charge of health or funeral affairs are obliged to immediately report the situation to the public prosecutor's office. In such cases, the deceased could only be buried with the written permission given by the public prosecutor after the necessary judicial proceedings on the body are completed. In deaths considered not to arise from natural causes, the forensic examination of the deceased should be performed and all medical signs and findings should be defined to determine the probable time of death and the most likely cause of death. This examination is conducted in the presence of the public prosecutor and by assigning a physician (CPC Art.86) (1). It is recommended that the body should be examined as soon as possible following the notification of death to the official authorities (2). Forensic postmortem examination should be performed at the place where the body is found when the environment and conditions are suitable, and in the morgue of the nearest health institution when not suitable. These examinations, which should primarily be performed by a forensic medicine specialist, are also conducted by physicians working in primary health care. The body is then sent to the autopsy center where the forensic specialist is located. In this process, since the findings on the body may change after death depending on the environment and conditions in which the body is located, all the findings found during the examination of the deceased must be fully and accurately defined and recorded by imaging (3).

In this study, we aimed to develop a standardized form that we consider will be a guide that will provide convenience to physicians participating in forensic death examination.

\section{MATERIALS and METHODS}

While creating the post mortem forensic examination form presented in this study, the general forensic examination reporting form recommended to be used in today's daily medical practice was taken as the sample. The form consisted of sections related to "determinants of medical identity", "postmortem findings", "injury-related lesions", "probable cause of death according to findings in the examination "and "decision made". Body diagrams were added to mark the locations of the lesions on the corpse.

In the first part of the form, blank spaces are given to fill in the following information: The date and time the report was issued, the report number, the authority requesting the post-mortem examination, the date and time of the examination, the place where the dead body was found, the conditions and time when the dead body was found, whether the clothes of the body were examined, the type of event thought to have caused death, a summary of medical records if the death occurred in hospital, and identity information of the body.

In the second part, sections added where examination findings defining the external characteristics of the body such as age, height, weight, hair color, skin color, and eye color that will indicate the medical identity of the dead person are recorded. In the third part, a section where the information will be written related to the medical history of the dead person and the blank spaces for the name-surname and the degree of affinity of the person from whom information about the dead was obtained were added.

In the following parts, checklist-style sections were added that would help to record the examination findings, including postmortem body temperature (cooling), post-mortem lividity (livor mortis), post-mortem stiffness (rigor mortis), and decomposition findings, accurately and completely. 
In the last part, the sections in which information about the probable cause of death and whether an autopsy was required would be written were included. Body diagrams of the male and female gender, on which the defined lesions would be marked, were added to the last two pages of this form, consisting of five pages (Appendix 1: Pictures).

\section{DISCUSSION and CONCLUSION}

As declared in the "Forensic Medicine Services Model and Manpower Planning" study conducted by the Association of Forensic Medicine Specialists (AFMS) because of the inadequate forensic medicine training given in medical faculties and the forgetting of the knowledge and skills gained in the faculty after graduation, it was reported that there are deficiencies in the process of forensic post-mortem examinations (5-8). When other studies in this field of research are examined, the deficiencies/insufficiencies in post-mortem examinations are not limited to our country (9-14).

The "National Core Education Program for Undergraduate Medical Education" (UÇEP/NCEP) was published in 2002 to procure international standards in medical education provided in our country, and it was updated in 2014 and 2020. According to the NCEP, it has been anticipated that post-mortem examination, which is one of the basic medical practices, can be performed in "uncomplicated, frequently seen situations/cases" (learning level 3) by graduate physicians (15). However, given that many universities providing medical education are not authorized for post-mortem examinations and autopsy procedures and the excessive number of medical students prevent the achievement of the desired post-mortem examination proficiency level in pre and post graduate education. This problem is attempted to be overcome in some training units by designing educational scenarios and applying these scenarios on dummies (16). Physician candidates who do not have sufficient practice during their education may overlook some significant findings in post-graduate forensic post-mortem examinations and misinterpret some findings. Deficiencies or inaccuracies occurring during these examinations may cause severe problems in the functioning of the justice system.

During the post-mortem examination, the physician should pay the utmost attention to prevent the loss of evidence that exists or appears on the body. In daily practice, while there is often no problem in identifying the medical findings on the corpse and determining the possible cause of death, problems may arise in estimating the probable time of death (17). Different tests and studies, such as measuring the response to electrical stimuli in muscles, measuring the response to chemical stimuli in the pupil, measuring changes in intraocular pressure, measuring potassium $(\mathrm{K}+)$ level in the vitreous humor, determining other chemical changes in body fluids, determining the status of gastric emptying, determining the status of gastric contents, defining changes in blood and bone marrow cells, are applied on the body to determine the time of death correctly. In addition to all these, especially recently, the time of death has been tried to be determined by research and tests conducted at the molecular level $(17,24)$. These laboratory studies mentioned above are not suitable for practical use and remain at the level of academic interest. In daily practice, generally, the findings emerging after death are used in determining the time of death. However, estimating the time of death based only on post-mortem changes can be misleading (24). More accurate estimates can be made by making use of the information, such as crime scene investigation, the testimony of eyewitnesses, telephone and camera records, included in the investigation information carried out by the judicial authorities $(17,24)$.

It has been reported that the majority of deaths occurred due to unnatural causes in our country that arise from traffic accidents (8,25-29). An autopsy is not performed in most of the deaths due to traffic accidents, in which the cause of death can be determined by evaluating the examination findings and medical records of the body (also autopsy is not recommended in such cases). However, in deaths due to traffic accidents in which the cause of death cannot be determined and in deaths that arise from other unnatural causes, an autopsy decision should be taken after the postmortem examination. After this decision, the body should be sent to an autopsy center where a forensic medicine specialist is located. As the time between post-mortem examination and forensic autopsy increases, post-mortem findings on the corpse may change. Therefore, the findings found during forensic post-mortem examination should be accurately defined and recorded by imaging.

Certain standardization is achieved in the reports issued by the physician in forensic cases with the preparation of general forensic examination reporting forms by the AFMS. However, there is no standardized form used for forensic postmortem examination in our country. The form presented in this article can be configured into a shape suitable for the needs of the users working in the field by taking the opinions and suggestions of forensic specialists under the leadership of AFMS. It is anticipated that the deficiencies in the postmortem forensic examination process can be reduced using this form.

\section{Ethics}

Ethics Committee Approval: Since this study is a review article, ethics committee approval is not required. Criteria of the Helsinki Declaration were considered while conducting this research and the writing of the article.

Peer-review: Internally peer-reviewed. 


\section{Authorship Contributions}

Concept: G.A., Design: G.A., Data Collection or Processing: M.Ö.P., C..M., Analysis or Interpretation: M.Ö.P., Ç.M., G.A., Literature Search: M.Ö.P., Ç.M., Writing: M.Ö.P., Ç.M.

Conflict of Interest: No conflict of interest was declared by the authors.

Financial Disclosure: The authors declared that this study received no financial support.

\section{REFERENCES}

1. Code of Criminal Procedure No. 5271. Last Accessed Date: 10.02.2020. Available from: https://www.mevzuat.gov.tr/MevzuatMetin/1.5.5271.pdf.

2. Madea B, Argo A. Certificatoin of death: external postmortem exmination. In: Madea B, ed. Handbook of forensic medicine. $1^{\text {st }}$ ed. West Sussex: John Willey \& Sons Ltd; 2014:57-74.

3. Koç S, Muhammed C. Ölüm kavramı ve ölü muayenesi. İçinde: Koç $S$, Muhammed C, editörler. Birinci Basamakta Adli Tıp. İstanbul: Türk Tabipler Birliği-İstanbul Tabip Odası; 2010:18-37.

4. General Forensic Examination Reporting Form. Last Accessed Date: 10.02.2020. Available from: https://dosyaism.saglik.gov.tr/ Eklenti/26519,geneladlimuayeneraporudoc.doc?0.

5. Adli Tıp Hizmet Modeli ve İnsan Gücü Planlaması. Adana; 2007. Available from: https://www.atud.org.tr/wp-content/uploads/2016/07/hizmet modeli.pdf

6. Katkıc U. Medicolegal autopsy cases in Sivas (1990-1995): demography and properties of forensic medical experts. Adli Tıp Bülteni. 1997;2(1):3-7.

7. Kumral B, Özdeș T. Assessment of physicians' approaches to the applications of forensic medicine in Tekirdağ province. Adli Tıp Dergisi. 2013;28(2):141 153. https://doi.org/10.5505/adlitip.2014.76376

8. Şengül HM, Ergönen AT. The investigation of the characteristics of women deaths and searching for violence against women in forensic autopsies performed in İzmir. DEU Tıp Derg. 2017;31(2):87-96

9. Karger B, Lorin de la Grandmaison G, Bajanowski T, Brinkmann B. Analysis of 155 consecutive forensic exhumations with emphasis on undetected homicides. Int J Legal Med. 2004;118(2):90-94. https://doi.org/10.1007/ s00414-003-0426-z

10. Minelli N, Marchetti D. Discrepancies in death certificates, public health registries, and judicial determinations in Italy. J Forensic Sci. 2013;58(3):705710. https://doi.org/10.1111/1556-4029.12114

11. Parai JL, Kreiger N, Tomlinson G, Adlaf EM. The validity of the certification of manner of death by ontario coroners. Ann Epidemiol. 2006;16(11):805-811. https://doi.org/10.1016/j.annepidem.2006.01.006

12. Perkins GD, McAuley DF, Davies S, Gao F. Discrepancies between clinical and postmortem diagnoses in critically ill patients: an observational study. Crit Care. 2003;7(6):R129-R132. https://doi.org/10.1186/cc2359

13. Ravakhah K. Death certificates are not reliable: revivification of the autopsy. South Med J. 2006;99(7):728-733. https://doi.org/10.1097/01. smj.0000224337.77074.57

14. Winkel BG, Holst AG, Theilade J, Kristensen IB, Thomsen JL, Hougen HP, et al. Differences in investigations of sudden unexpected deaths in young people in a nationwide setting. Int ] Legal Med. 2012;126(2):223-229. https://doi. org/10.1007/s00414-011-0602-5

15. National Core Education Program for Undergraduate Medical Education -2020 Last Accessed Date:10.07.2020. Available from: https://www.yok.gov. tr/Documents/Kurumsal/egitim_ogretim_dairesi/Ulusal-cekirdek-egitimiprogramlari/mezuniyet-oncesi-tip-egitimi-cekirdek-egitimi-programi.pdf.

16. Zeybek V, Acar K, Dereli AK, Kara CO. Evaluation of forensic postmortem examination training on the model in context of structured scenario. Adli Tıp Bülteni. 2018;23(1):6-12. https://doi.org/10.17986/blm.2018136913

17. Madea B, Henssge C, Reibe S, Tsokos M, Kernbach-Wighton G. Postmortem changes and time since death. In: Madea B, editor. Handbook of forensic medicine. $1^{\text {st }}$ ed. West Sussex: John Willey \& Sons, Ltd; 2014:75-133.

18. Balci Y, Basmak H, Kocaturk BK, Sahin A, Ozdamar K. The importance of measuring intraocular pressure using a tonometer in order to estimate the postmortem interval. Am J Forensic Med Pathol. 2010;31(2):151-155. https:// doi.org/10.1097/PAF.0b013e3181dd7933

19. Dokgoz H, Arican N, Elmas I, Fincanci SK. Comparison of morphological changes in white blood cells after death and in vitro storage of blood for the estimation of postmortem interval. Forensic Sci Int. 2001;124(1):25-31. https://doi.org/10.1016/S0379-0738(01)00559-X

20. Forger LV, Woolf MS, Simmons TL, Swall JL, Singh B. A eukaryotic community succession based method for postmortem interval (PMI) estimation of decomposing porcine remains. Forensic Sci Int. 2019;302:109838. https:// doi.org/10.1016/j.forsciint.2019.05.054

21. Madea B. Is there recent progress in the estimation of the postmortem interval by means of thanatochemistry? Forensic Sci Int. 2005;151(2-3):139149. https://doi.org/10.1016/j.forsciint.2005.01.013

22. Nolan AN, Mead RJ, Maker G, Bringans S, Speers SJ. The impact of environmental factors on the production of peptides in mammalian decomposition fluid in relation to the estimation of post-mortem interval: a summer/winter comparison in Western Australia. Forensic Sci Int 2019;303:109957. https://doi.org/10.1016/j.forsciint.2019.109957

23. Wang H, Ma J, Xu H, Lyu Y, Tao L, Li W, et al. Early Postmortem Interval (EPMI) Estimation Using Differentially Expressed Gene Transcripts. Leg Med (Tokyo). 2019;38:83-91. https://doi.org/10.1016/j.legalmed.2019.04.008

24. Aydin B, Colak B, Balci Y, Demirustu C. Consistency of postmortem interval estimations of physicians using only postmortem changes of putrefied dead bodies. Am J Forensic Med Pathol. 2010;31(3):243-246. https://doi. org/10.1097/PAF.0b013e3181ee01d9

25. Akar T, Bakar C, Şenol E, Demirel B. Evaluation of medico-legal death investigations per- formed in Gazi University Medical Faculty Gazi Hospital. Gazi Medical Journal. 2005;16(4):169-171.

26. Yağmur F, Din H. Evaluation of forensic postmortem examination and autopsies cases performed in Kayseri, 2007. J Forensic Med. 2009;23(2):1824

27. Altun G, Azmak D, Yılmaz A, Yılmaz G. The characteristics of the cases which admitted to emergency department of Trakya University Medical Faculty. Adli Tıp Bülteni. 1997;2(2):62-66.28. Korkmaz T, Kahramansoy N, Erkol Z, Sarıçil F, Kılıç A. Evaluation of medicolegal reports prepared in emergency department Haseki Tıp Bülteni. 2012(50):14-20.

29. Ilçe A, Erkol MH, Alpteker H, Erkol ZZ. Retrospective analysis of forensic case reports who had applied to the emergency service in the city centre of Bolu. Abant Med J. 2018;7(3):68-75. https://doi.org/10.5505/ abantmedj.2018.31957. 
Annex 1. Forensic postmortem examination reporting form

\section{POST-MORTEM FORENSIC EXAMINATION FORM}

Republic of Turkey

The Institution of the Doctor Conducting Post-mortem Forensic Examination:

Report Date and Time:

Report Number:

The Requesting Institution:

FOR THE EXAMINED DECEASED:

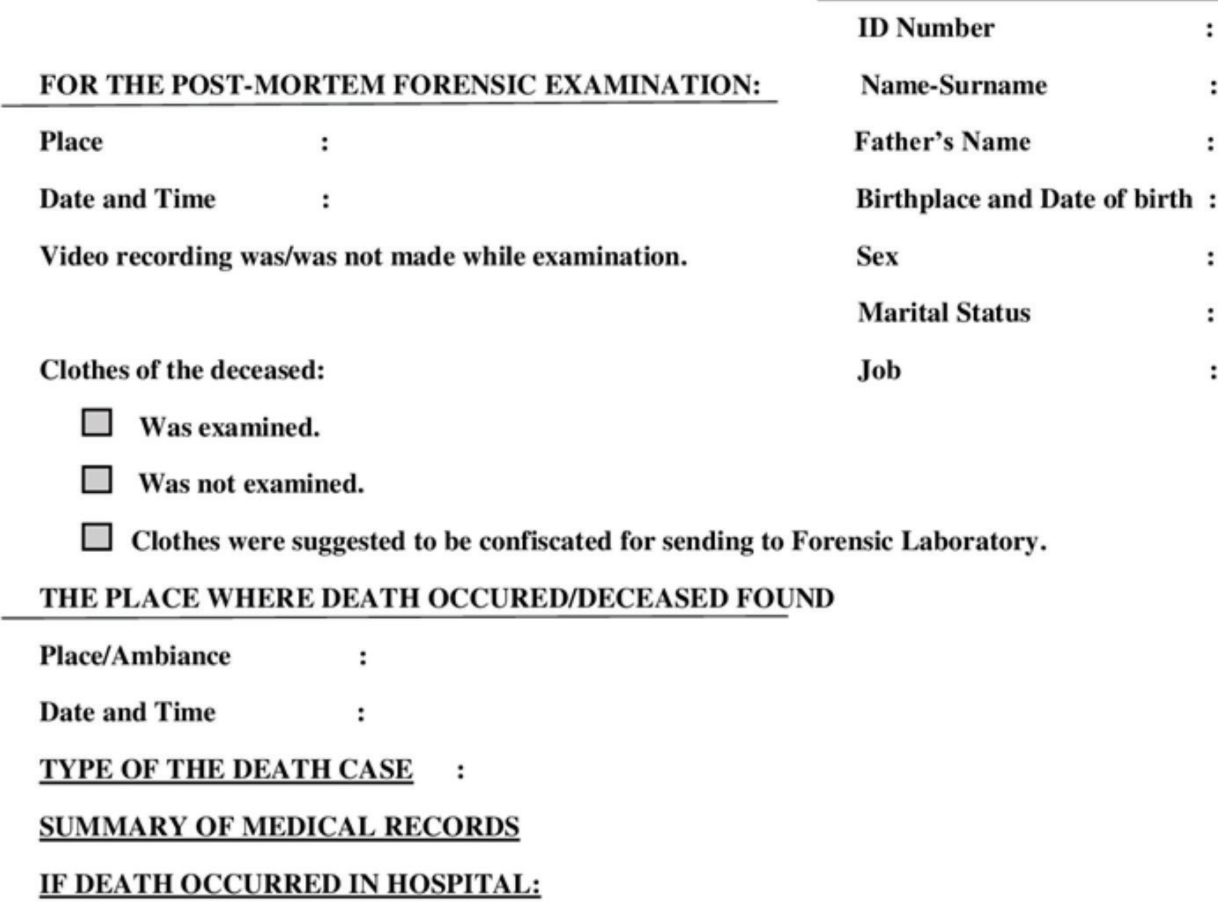

\section{MEDICAL IDENTIFICATION / PHYSICAL CHARACTERISTICS OF THE DECEASED :}

Age : $\quad$ Hair color : $\quad$ Shaving :

Weight : $\quad$ Eye color : $\quad$ Mustache-Beard: $\quad$ Tattoo :

$\begin{array}{lllll}\text { Height }: & \text { Skin color } & \text { Circumcision } & \text { Scar }\end{array}$

MEDICAL HISTORY OF DECEASED :

NAME-SURNAME AND RELATIONSHIP OF THE PERSON

WHO GAVE INFORMATION ABOUT THE DECEASED:

This report is ...... pages with additional forms and each page has three copies. 
POST-MORTEM FORENSIC EXAMINATION FORM

Name-Surname of the Deceased:

Report Number:

ALGOR MORTIS (BODY COOLING): (If the body has not been placed in the mortuary refrigeration, evaluate.)

Hot to the touch : $\square \quad$ Warm to the touch : $\square \quad$ Cold to the touch :

Rectal Temperature : $\quad$ Environmental Temperature :

\section{HYPOSTASIS :}

Not ocured : $\square$ Patchy $\quad: \square \quad$ Ocurred on unpressured surfaces

Displace with thumb pressure $: \square$ Not displace with thumb pressure

Marked in front Body $\quad: \square \quad$ Marked in back body

Marked in extremities : $\square$ Marked in head\&neck:

Purple :

Red :

Pink :

Brown :

\section{RIGOR MORTIS :}

Not occured

In the smaller joints

In the bigger joints

: a) Total stiffness

: $\square$

b) Partial stiffness :

POST-MORTEM DECOMPOSITION : (If you are not familiar with the meaning of the following terms, please describe the changes that you have detected on the body and take a photo of them.)

Greenish discoloration in the right iliac fossa

: $\square$ Chest \& abdomen swollen: $\square$

Marbling of the skin :

Discoloration of the whole body

: $\square$ Skin blisters

Skin-slippage

Adipocere formation

: $\square \quad$ Maceration

Mummification 


\section{POST-MORTEM FORENSİC EXAMINATION FORM}

Name-Surname of the Deceased:

Report Number:

\section{LESION(S)}

$\square$ Head\&Neck $\square$ Chest $\square$ Abdomen $\square$ Back\&Low back $\square$ Upper extremities $\square$ Lower extremities $\square$ Genitalia

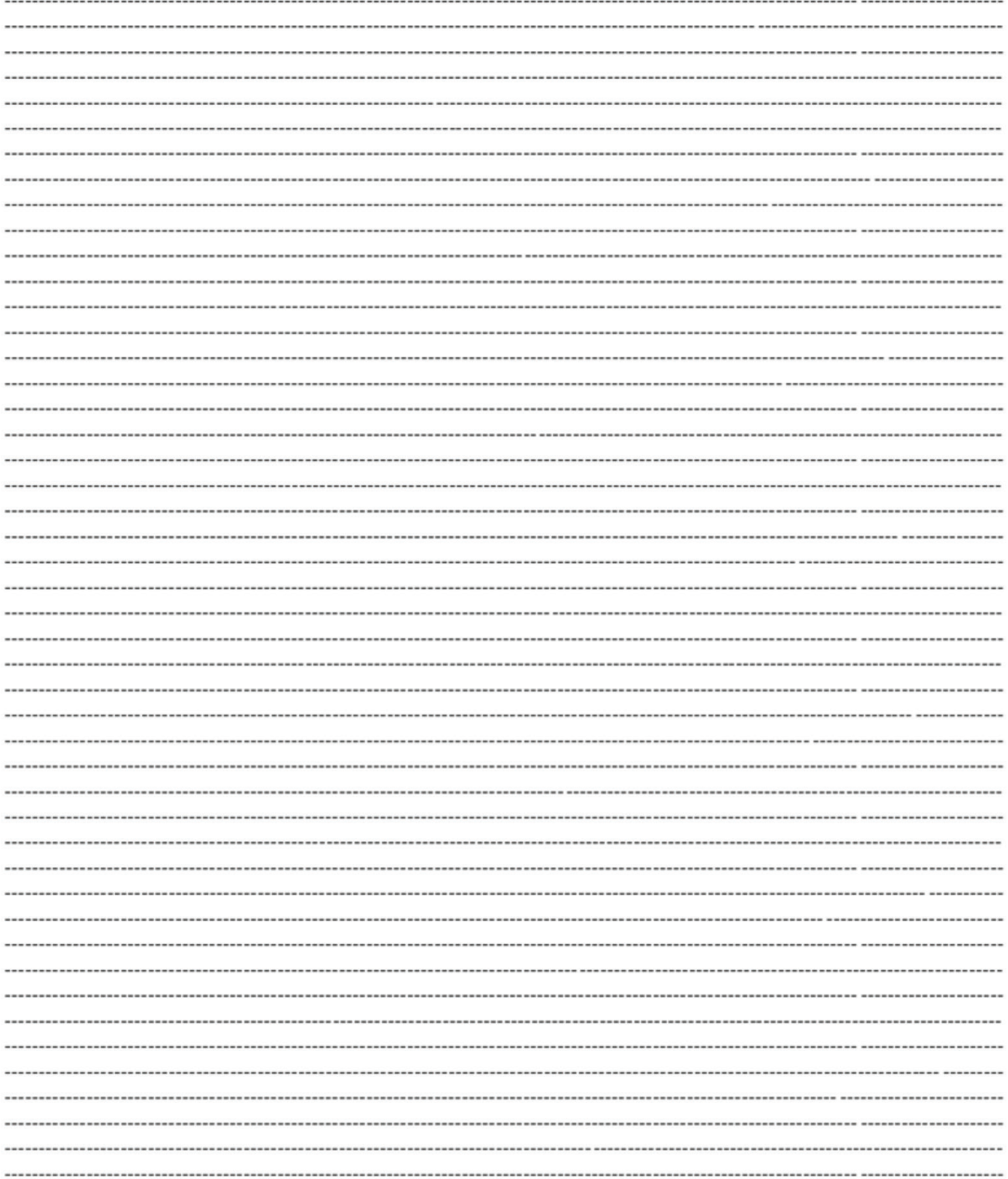


POST-MORTEM FORENSIC EXAMINATION FORM

Name-Surname of the Deceased:

Report Number:

CONCLUSION: (Write medical terms without abbreviation, please.)

According to the post-mortem examination (cause of death/autopsy decision); It was concluded that;

a) The death caused by ..........................., there is no need to autopsy. (This decision can be made if the death is due to a traffic accident but still an autopsy is recommended.)

b) The death caused by ..........................., but for evidence obtaining there is need to autopsy.

c) Since the exact cause of the death has not been determined, an autopsy is required.

Medical Doctor:

Signature:

Registration Number: 
Name-Surname of the deceased:
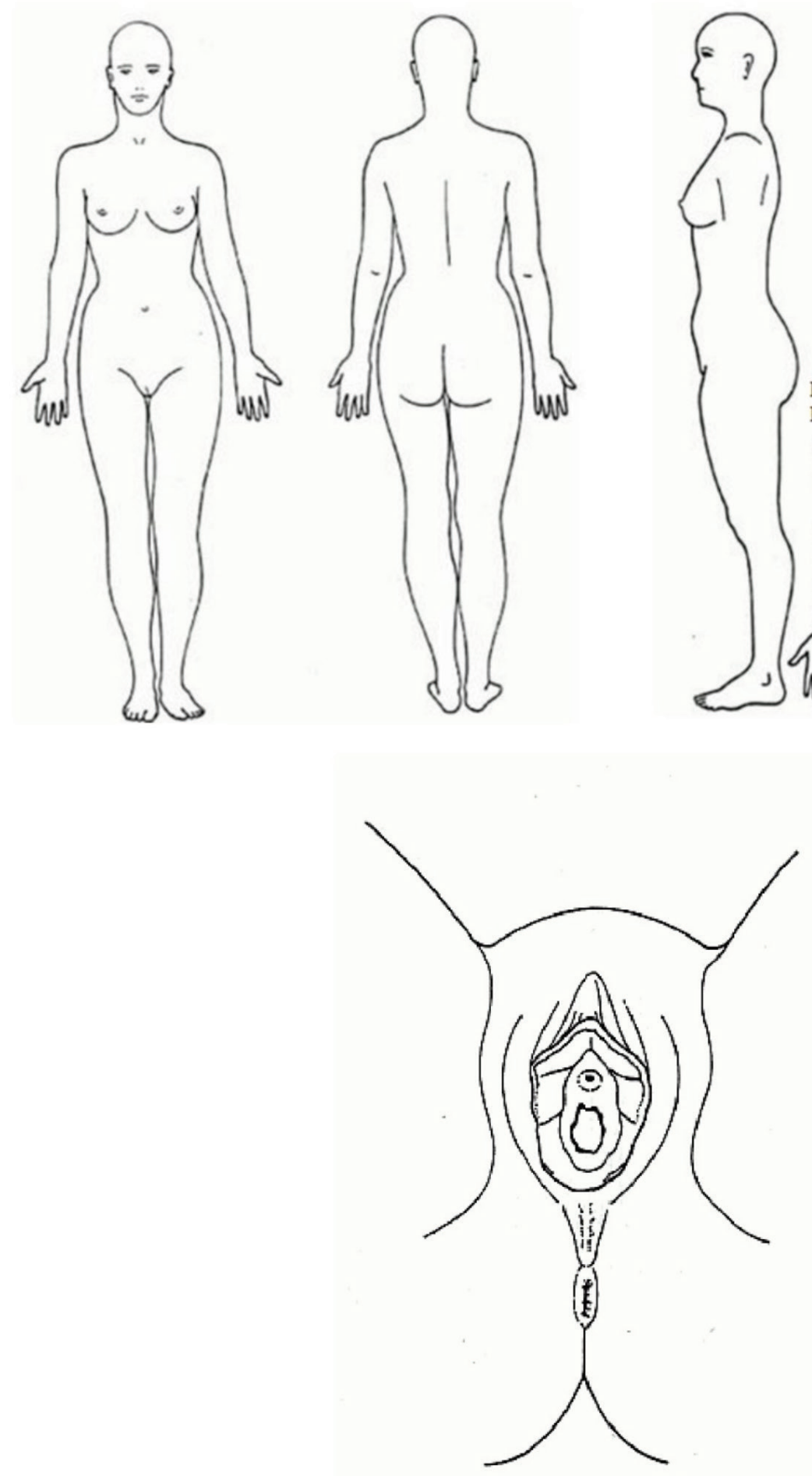

Report Number :
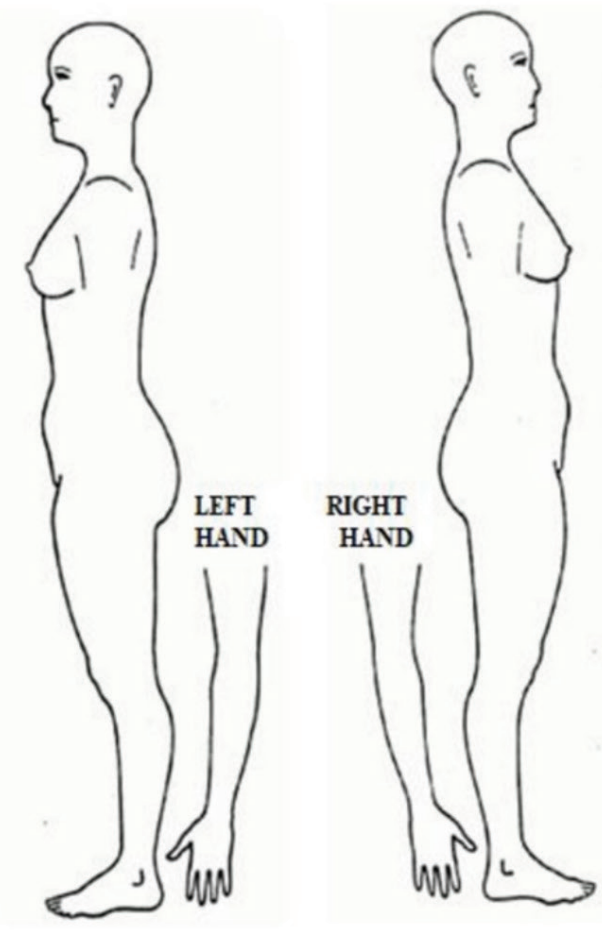
POST-MORTEM FORENSİC EXAMINATION FORM

(For Man)

Name-Surname of the deceased:

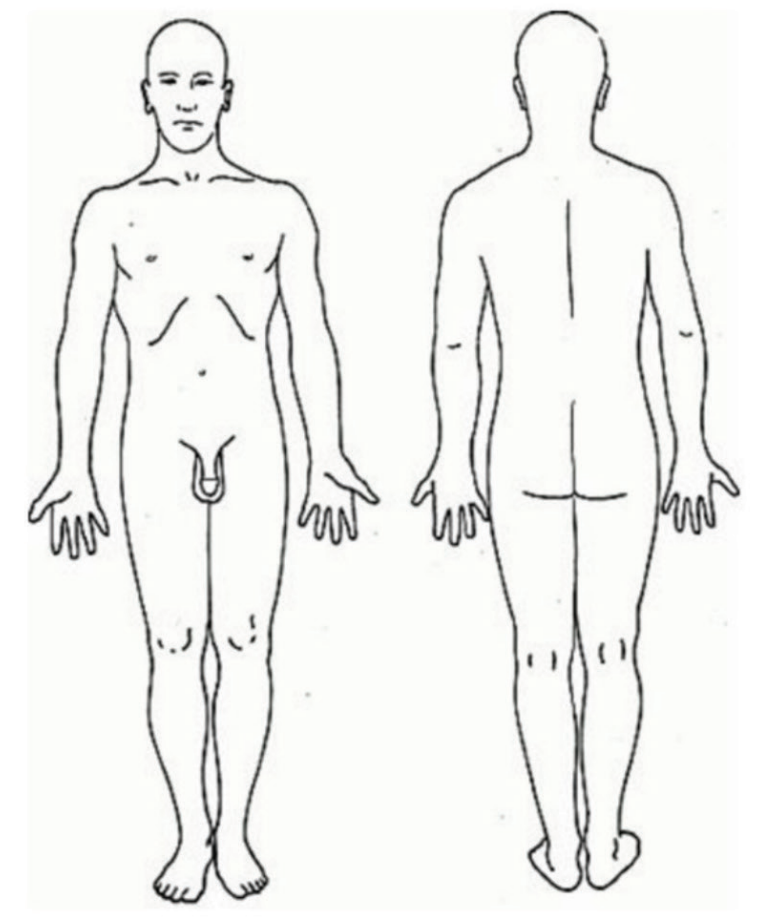

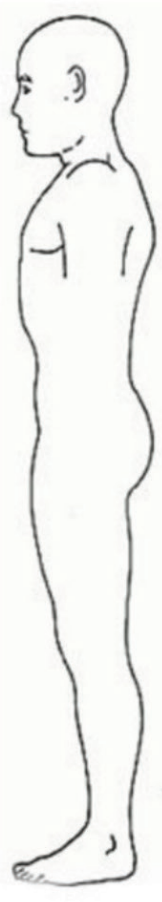

Report Number :

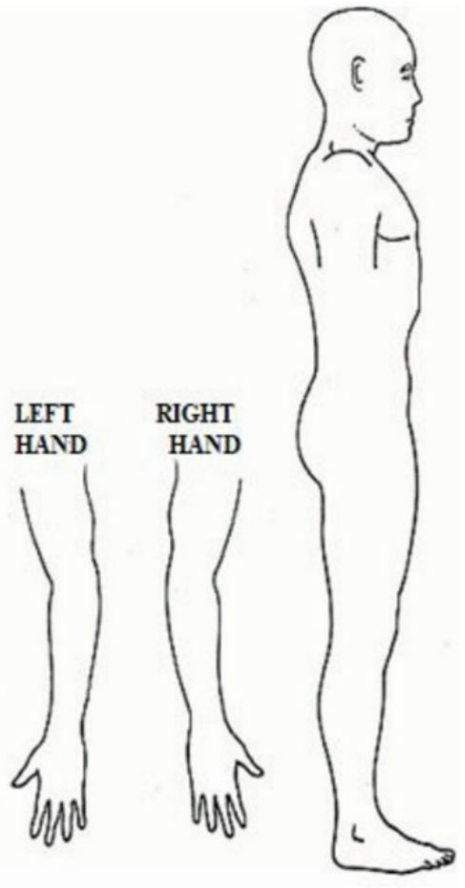

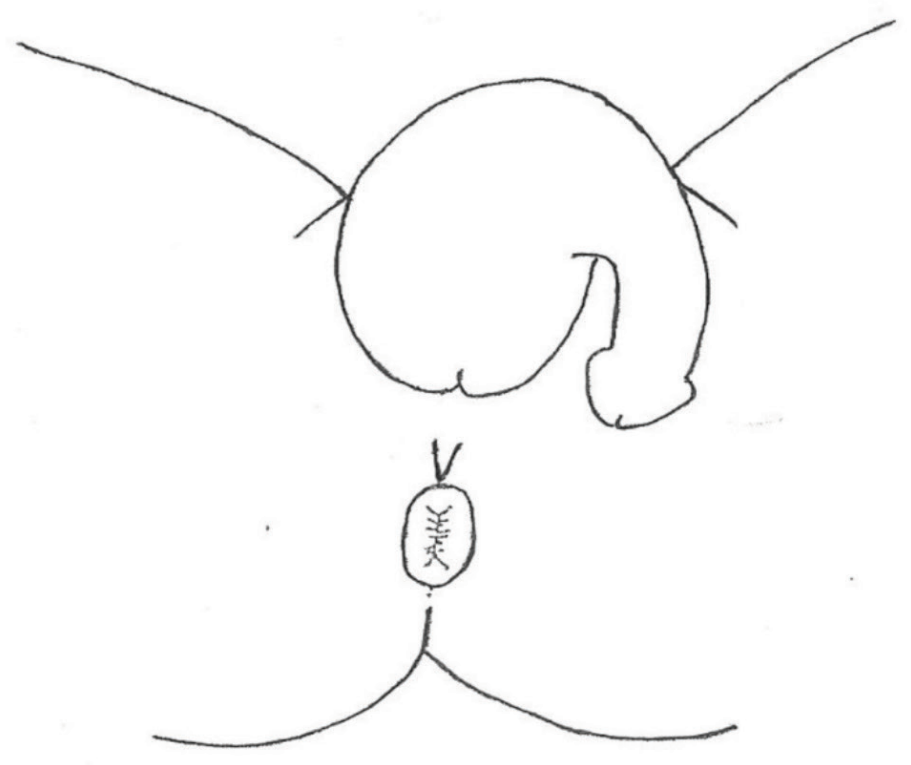

